\title{
A Cognitive and Intellectual Resource: A Book Review of Psychological Assessment with the MMPI-2/MMPI-2-RF, Third Edition, 2015
}

\author{
Alan M Jaffe* and Melanie J Thakkar \\ ${ }^{1}$ Department of Psychiatry, Northwestern University Feinberg School of Medicine, USA \\ ${ }^{2}$ Department of Clinical Psychology, Illinois School of Professional Psychology, USA
}

Submission: March 01, 2019; Published: March 11, 2019

*Corresponding author: Alan M Jaffe, Department of Psychiatry, Northwestern University Feinberg School of Medicine, USA

Keywords: Cognitive; Adjunct; Restructured; Descriptors; Development; Interpretation

\section{Short Communication}

Friedman and his colleagues in this third edition of their textbook provide their readership with a broadened discussion built upon the second edition of their book. The MMPI-2 is an assessment instrument, which is useful adjunct to assessing intellectual and cognitive functioning. This edition is supplemented with two additional chapters including the development and interpretation of the Restructured Clinical (RC) scales and the Restructured Form (RF) of the MMPI-2. The University of Minnesota Press released the RF in 2008. The RF was intended as an alternative addition to, rather than a replacement, for the MMPI-2. This revised book contains a section which provides codetype descriptors for the MMPI-2 and is expanded to include narratives to include useful feedback for patients/clients, which cover most of the 104 codetypes. This updated text includes more than 250 additional references.

In-depth interpretations of the supplementary and content scales as well as the critical items are provided by the authors. Their chapter on interpretation and report writing is very useful for new MMPI-2 users learning how to compose personality assessment reports. An increased discussion of validity scale interpretations is useful for those who administer testing where clients may be inclined to under- or over-report their complaints.

The section that presents the cognitive complaints scale (COG) contains items which refer to a broad range of cognitive/ intellectual complaints and developmental/intellectual limitations. The authors report that high scores on the cognitive complaints (COG) scale are associated with intellectual interference difficulties, low frustration tolerance, memory complaints, and stress and worry along with generalized concentration and subsequent learning difficulties. Important in delineating intellectual assessment the authors cite Gervais, Ben-Porath \& Wygant (2009) who note that cognitive complaints scale (COG) scores are not an effective predictor of objectively assessed cognitive function. They are primarily associated with emotional distress rather than neurological symptoms.

As a measure which fortifies the assessment of intellectual capacity, the authors discuss the mental dullness scale, which is a subscale of depression and reflects the cognitive weakening by the depressive process. High scores imply a loss of interest, a sense of intellectual failure or decline, and the reduction of necessary energy needed to accomplish mental work. The authors cite Alex Caldwell (1988) who referred to this reflection of intellectual decline represented in this scale as the "mental fog" of depression. The themes of this subscale consist of being easily distracted, unable to comprehend what one reads, and suffering memory and judgment issues. The authors note that this is in contrast to the Graham et al., 1999 investigation of psychiatric outpatients, which did not reveal marked concentration difficulties in high scorers of the mental dullness subscale. In this version of the textbook the authors found that low scorers on the intellectual measure of the mental dullness scale are unable to be as cognitively efficient as other individuals.

There is a practical review of the problematic Symptom Validity Scale (formerly named the Fake-Bad Scale [FBS]), 
which gained prominence and notoriety when the publisher added the scale in 2007. The authors caution test users about the deficiencies of this scale by reviewing the development and research and their reasons for the recommendation against its use. Specifically, they cite judicial decisions invoking the Frye standard for its failure to meet criteria for admissibility in personal injury/disability cases.

The last chapter educates the reader about computerized reports and compares three different automated narrative assessments for the same patient in order to illustrate the similarities and differences between products, including the RF. There is also an added section in the book on predicting suicide using the MMPI-2 scales, which use is especially informative.
This well-organized textbook provides research and easyto-follow interpretation guidelines, including cutting scores for most of the important and well-used scales on both the MMPI2 and MMPI-2-RF. It is comprehensive in its coverage, and is a solid work of scholarship, which is recommended for seasoned practitioners, students, and researchers desiring a reference guide for interpreting and understanding of MMPI test results. Furthermore, attorneys will most likely find the book invaluable in better understanding the construction of various scales and interpretations often used in forensic settings.

\section{Your next submission with Juniper Publishers will reach you the below assets}

- Quality Editorial service

- Swift Peer Review

- Reprints availability

- E-prints Service

- Manuscript Podcast for convenient understanding

- Global attainment for your research

- Manuscript accessibility in different formats

( Pdf, E-pub, Full Text, Audio)

- Unceasing customer service

Track the below URL for one-step submission https://juniperpublishers.com/online-submission.php 